\title{
MARKET PARTICIPATION DECISION OF SMALLHOLDER FARMERS AND ITS DETERMINANTS IN BANGLADESH
}

\author{
Ataul Gani Osmani ${ }^{1}$, Elias Hossain ${ }^{2}$
}

\begin{abstract}
Summary
This paper explores the market participation decision of smallholder farmers in Bangladesh and tries to sort out the most important factors that influence smallholder farmers'decision to participate in the output market to sell their produce in Bangladesh. To examine the relationship between the smallholder farmers' decision to participate in the market and the factors that affect these farmers' decision, a Probit regression model is employed. For this purpose this study uses primary data collected from 100 smallholder farmers of Durgapur Upazila under Rajshahi District. Main findings of this study indicate that there is moderate level of market participation by the households who decide to participate in the market with 57\% sales of their produced crops. It is found that farm size, household labour, income from livestock and farm income might be the main factors that affect the smallholder farmers' decision to participate in the output market. These findings also suggest that the smallholder farmers would participate more and more in the output market, if farm size, household labour and farm income are increased in one hand and income from livestock is decreased on the other hand. The originality of this paper is that it examines the phenomenon of smallholder farmers' commercialization in Bangladesh from the perspectives of market participation, which may create an opportunity for further constructive debate. Finally, development market infrastructure, provision of marketing incentives to smallholder farmers and development of an institutionalized marketing information service are recommended to enhance commercialization of agriculture in Bangladesh.
\end{abstract}

Key words: Bangladesh, agricultural commercialization, market participation, Probit regression, marketing incentives.

JEL: $Q 16, M 24$

1 Md. Ataul Gani Osmani., Researcher, Department of Economics, University of Rajshahi, Rajshahi 6205, Bangladesh, Phone: +880 17191937 87, E-mail: ataul.economics@yahoo.com

2 Md. Elias Hossain, Ph.D., Professor, Department of Economics, University of Rajshahi, Rajshahi 6205, Bangladesh, Phone: +880 17121041 01, E-mail: eliaseco@ru.ac.bd

EP 2015 (62) 1 (163-179) 


\section{Introduction}

Agriculture continues to be a strategic sector in the development of most low-income nations like Bangladesh where smallholder farming is the dominant livelihood activity (SFB, 2015). This sector contributes around $16.77 \%$ to the gross domestic product (BBS, 2013) and provides employment for about $47.3 \%$ of the total labour force of the country (BBS, 2010). In the financial year (2013-14) until July-February, Bangladesh earned US\$ 899.0 million by exporting agricultural products which was $4.53 \%$ of total export earnings of the country $(\mathrm{GoB}, 2014)$. In Bangladesh, smallholder farming accounts for $96 \%$ of its total operational holdings with a share of $69 \%$ of total cultivated area (Thapa, Gaiha, 2011). As most of the farmers in the country are marginal and small farmers, strong agricultural growth in the country may be achieved through the performance of smallholder farming.

Commercialization of agriculture means greater market orientation of goods produced by the farmers (Pingali, 1997). Agricultural commercialization usually takes a long transformation process from subsistence to semi-commercial and then to a fully commercialized agriculture with the main objective of achieving food self-sufficiency (Pingali, Rosegrant, 1995). Although agriculture in Bangladesh has contributed to increasing food self-sufficiency over the last 30 years, the participation in the commercialization process has been a difficult task for the smallholder farmers because of inappropriate policies, insufficient access to technology, institutional obstacles, weak infrastructure and unfortunate links to markets (Sharma et al., 2012). The self-sufficiency in food is continuously threatened in Bangladesh by an increasing population and stagnating agricultural yields (World Bank, 2015). The stagnation of agricultural productivity in Bangladesh occurs in many cases due to absence of commercialization of agriculture. As the productivity of farmers in Bangladesh is low, they cannot have surplus products and fail to participate in market. The terms upon which the smallholders enter and participate in output markets are sometimes inequitable. Many of the smallholder farmers in Bangladesh are currently passive participants, often obliged to sell low (immediately after harvest) and buy high, with little choice of where they conduct transactions, with whom, and at what price (IFAD, 2001). The asymmetric structure of many markets, high transactions cost and the lack of skills, information and organization may represent these substantial barriers to accessing small farmers into markets. Moreover, remoteness, scarce and poorly maintained roads, inadequate transport and storage facilities, and difficulties in accessing reliable information on products and prices prevent the smallholder farmers from participating in competitive markets, often restricting them to non-contestable markets dominated by a few, powerful purchasers (World Bank, 2007).

In the World Development Report 2008, it was argued that improving productivity, profitability and sustainability of smallholder farming is the main pathway to reduce poverty in the developing countries (World Bank, 2007). With the introduction of modern technologies and provision of various supports from the government authorities, agricultural production system in many developing countries is turning to be a commercialized one. In Bangladesh also agricultural production system has gradually been transforming from subsistence farming to commercial agriculture (Razzaque, Hossain, 2007; GoB, 2008). In recent years, smallholder farmers in Bangladesh are also taking part in market to sell some portion of their products. 
Thus, smallholder farming has an important role in transforming Bangladesh agriculture from subsistence to market oriented production or commercial agricultural production. Now, it is observed that commercialization of agriculture can be achieved by promotion of value addition to high valued agricultural commodities, particularly horticultural and dairy products which supports agri-businesses and links farmers with markets (World Bank, 2007). For this purpose, National Agricultural Technology Project (NATP) of Bangladesh financed by the World Bank and International Fund for Agriculture Development (IFAD) integrates small and marginal farmers in Bangladesh recently who produce rice, maize, fruits, vegetables, livestock, fisheries etc. into value chains. Thus, the smallholder farmers are now producing more products to meet the domestic demand and export some portion of their products in other countries in the world (MoA, 2013). Moreover, Integrating Smallholder into Expanding Markets (ISEM) project, 2011-2012, in Bangladesh facilitates poor rural households to participate in high value agriculture market systems effectively and to move from subsistence to small-scale commercial farming.

Unfortunately, not much research has been conducted to verify the major factors responsible for dismal market participation by farmers, especially those in developing economies such as Bangladesh. This work is an attempt to fill the research gap and contributes to the generation of evidence for policy makers to realize greater market participation of smallholder farmers in Bangladesh. It is also necessary to do this research in the context of Bangladesh where there is observed increase in the population and farmers in the face of widespread poverty. The broad objective of this research, therefore, is to provide empirical information on households' involvement in the output market and to determine the factors that affect the market participation decision of smallholder farmers in Bangladesh using statistical and econometric approaches. Thus, the study may generate new empirical information on the simultaneous interaction of household decisions of market participation and the most influencing factors of the market participation of smallholder farmers in Bangladesh.

\section{Literature Review}

There are a number of determinants of market participation of smallholder farmers and are broadly categorized as external and internal factors. The external ones are factors like population growth and demographic changes, technological change and introduction of new commodities, development of infrastructure and market institutions, development of nonfarm sector and broader economy, rising labour opportunity costs, and macroeconomic, trade and sectoral policies affecting prices and other driving forces (von Braun et al., 1991; Pingali, Rosegrant, 1995). In addition, development of input and output markets, institutions like property rights and land tenure, market regulations, cultural and social factors affecting consumption preferences, production and market opportunities and constraints, agroclimatic conditions, and production and market related risks are other external factors that could affect the commercialization process (Pender et al., 2006). On the other hand, factors like smallholder resource endowments including land and other natural capital, labour, physical capital, human capital etc. are household specific and considered internal determinants of market participation. 
Household asset holdings, both in terms of capital and as a buffer to mitigate any production and market related shocks, are relevant in a smallholder commercialization process. Assets like land, oxen, farm implements, and human capital are essential for marketable surplus production at a smallholder level. Larger farm holdings enable households to exercise economies of scale by adopting modern technologies (von Braun, Immink, 1994). These and other assets for surplus production become critical, especially when markets for land and oxen power are completely missing or less functional. When factor markets are imperfect, resource ownership matters for efficiency (Sadoulet, de Janvry, 1995). In addition, household asset holding in the form of human capital is one of the crucial elements in commercializing smallholder agriculture. Human capital comprises education, experience, skills, capabilities etc. of the household members engaged in pursuing new opportunities that could change the household's overall living standards (World Bank, 2007).

Farm household's decision to participate in the market can be affected by different factors in the context of different developing countries. The scale of commercialization in one enterprise enhanced commercialization in the other and household's scale of commercialization in the two enterprises was determined by common factors. For example, the crop and livestock commercialization status are independent and the determinants are different (Goshu et al., 2012). The decision of smallholders to enter markets is influenced by many household (micro) and macro level factors (Gebreselassie, Ludi, 2008). Macro-economic and trade policies, market reform, rural infrastructure improvement and the development of legal and contractual environments in which smallholders and processors may operate are among the major driving forces of increased agricultural commercialization (Gebreselassie, Sharp, 2008).

Thus, the important determinants of commercialization are land size, gender of household head, livestock assets, ethnicity, education and location (Rahut et al., 2010). The result of empirical study of Gebremedhin and Jaleta (2010a) showed that commercial transformation of subsistence agriculture depends on both the determinants of market orientation and the determinants of market participation in crop output market, but market orientation can strongly be transformed into market participation. The intervention to enhance market orientation can be helpful in promoting market participation and the interventions to uphold market participation may not be sufficient to uphold market orientation. In addition, the distance to the nearest market and the availability of market information are found to be significant factors in households' degree of commercialization (Eskola, 2005). According to Egbetokun and Omonona (2012) the major determining factors influencing farmer's participation in the market are age, marital status, source of labour, farming experience, farm size. The probability of participating in output markets depends on household size, distant to the nearest marketing channel, price of the commodity and sex of the farmer (Onoja et al., 2012). The econometric analysis of Pender and Alemu, (2007) shows that increasing production of food crops is the most important factor contributing to increased sales and that increased smallholder access to roads, land, livestock, farm equipment, and traders are key to enabling increased smallholder production and commercialization of these crops. Moreover, Ele et al. (2013) finds that total quantity of food crops produced, 
farming experience, access to agricultural extension service, size of land used for cultivation, membership in cooperatives and household family size are important factors determining the level of commercialization of smallholder farms. Therefore, analysis of the factors affecting market participation decision of smallholder farmers will help to design appropriate policy instruments, institutions and other interventions for their sustainable economic development. The degree of market participation of smallholder farmers depends on many factors including age of household heads, household size, food security, access to fertilizers and benefits derived from participation in farmer organizations (Chirwa, Matita, 2012). Similarly, both the total value of farm production and the proportion of land allocated to the major cash crop had a positive and significant impact on a household's degree of market participation, measured in terms of gross income from crop sales (Gebreselassie, Sharp 2008).

\section{Study Area and Sample Selection}

The present study is mainly based on primary data collected from the smallholder farmers of six villages from three unions of Durgapur Upazila under Rajshahi district. The total population of the district is 2,262,483 of which $51.20 \%$ are male and $48.80 \%$ are female. The main occupation of the people of the district is agriculture. About $59.4 \%$ people of Rajshahi district involve with agriculture followed by commerce $14.3 \%$, service $8.9 \%$, transport and communication $4.4 \%$, non-agricultural labour $3.4 \%$, construction 1.5\% etc (BBS, 2011). Durgapur Upazila of Rajshahi district is an agriculture dependent area. The total area of the Upazila is $195.03 \mathrm{sq} \mathrm{km}$. with total population of 2,595,197 of which 1,309,890 are male and 1,285,307 are female (BBS, 2011). From this Upazila, the sample farmers are chosen randomly using multistage random sampling method. For analyzing the market participation decision of smallholder farmers and its determinants, the sample has been selected in such a way that it covers all necessary data required for analysis. For conducting present study, we selected the study area with great care so that the estimated results become are representative. The rationale behind selecting Rajshahi for the present study is that Rajshahi district is an agriculture-based area. Rice is the dominant crop produced simultaneously with other minor crops such as wheat, potato, vegetables, jute, maize, oilseeds, pulse, onion, garlic etc. in the district. Farming is the principle occupation of most of the population and their livelihood mostly dependent on agricultural activities. In this area, farming is characterized by low level of production technology and small size of land holding. Production is primarily subsistence with little surplus for marketing. Around $80 \%$ people of study villages are farmer. In Rajshahi district there is sufficient scope to improve crop production using the improved technologies. For above-mentioned reasons the researcher has chosen Rajshahi district for conducting the research.

Since the researcher is constraint by time and other resources one Upazila-Durgapur was selected purposively for this study. From this Upazila, three unions are chosen randomly, taking two villages from each. There are 1 Pourosova, 7 unions and 124 villages in Durgapur Upazila. Firstly, the researcher selected three unions randomly. 
The selected unions are Noapara, Deluabari, and Jhaluka. In the next stage, two villages from each union are selected randomly. The selected villages are Nondigram and Kashipur from Noapara union, Vobanipur and Bera from Deluabari union and, Coupukoria and Shaheber from Jhaluka union. Next, and then the researcher selected 100 respondents from the three sample Unions using the systematic random sampling method. Finally, a list of all smallholder farmers is collected from the agriculture extension office of Durgapur and then sample households are chosen randomly from these six villages. A total of 100 farm households are selected for this study. The total sampling information is presented in the following Table.

Table 1. Selection of the Respondents

\begin{tabular}{|c|c|c|}
\hline Name of Union & Name of Village & Number of Sample \\
\hline \multirow{2}{*}{ Noapara } & Nondigram & 17 \\
\hline & Kashipur & 16 \\
\hline \multirow{2}{*}{ Deluabari } & Vobanipur & 20 \\
\hline & Bera & 15 \\
\hline \multirow{2}{*}{ Jhaluka } & Coupukoria & 16 \\
\hline & Shaheber & 16 \\
\hline Total & 6 & 100 \\
\hline
\end{tabular}

Source: Authors' calculations according to data from Osmani, Hossain (2013)

\section{Model for Market Participation Decision}

Most of the farmers in Bangladesh are marginal and small farmers and they have limited participation in the output market. Some farmers are subsistence farmers and cannot participate in the market to sell their product. However, recently farmers are adopting modern technologies and their productivity has increased. Thus, this facilitates them to participate in the market through selling their surplus products. A smallholder farmer's decision to take part in market is influenced by many socio-economic and farm specific characteristics (Gebreselassie, Sharp, 2008; Gebreselassie, Ludi, 2008; Gebremedhin, Jaleta, 2010b). As per the study of Egbetokun and Omonona (2012), a Probit model is used in this study to identify such factors. The relationship between market participation decision and the factors that affect the decision can be formulated as follows:

$$
Y_{i}=f\left(X_{i}, D_{i}\right)
$$

Where,

$\mathrm{Y}_{\mathrm{i}}=$ Market participation decision by a household

$\mathrm{X}_{\mathrm{i}}=$ Continuous factors of market participation decision

$\mathrm{D}_{\mathrm{i}}=$ Qualitative factors of market participation decision (dummy)

According to Gebreselassie and Ludi (2008), in this study the market participation decision is estimated as $\mathrm{Y}=1$ if the household participates in output markets and $\mathrm{Y}=$ 0 otherwise. Following von Braun, Immink (1994), we can compute household crop output market participation in annual crops as the proportion of the value of crop sales 
to total value of crop production, which can be computed as follows:

$$
\text { Market participation }=\frac{\text { Total value of crop sales }}{\text { Total value of crop production }}
$$

Given the nature of market participation level, the farmers are said to be market participant if their proportion of value sold is more than 75\% (Goletti, 2005; Ohen et al., 2013). Thus, the researcher defined the binary response variable as $Y=1$ if the farmer's crop sales exceed a threshold or critical level of $Y^{*}(75 \%)$ and $Y=0$ if $Y \leq Y^{*}$. Here, the proportion of crop sold (say, above 75\%) out of the total production by the smallholder farmers in the production year used as the proxy of market participation during data collection period (Moyo, 2010).

Siziba et al. (2011) observed that off-farm income, ownership of farm equipment's, and number of livestock owned were highly significant asset variables. Socioeconomic characteristics such as age, education, farm size, ownership of some assets and output were observed to have positive effect on market participation of various agricultural commodities (Olwande, Mathenge, 2012; Omiti et al., 2009; Randela et al., 2008). Public assets variables have also been found to have positive relationship with market participation especially with respect to access to credit and insurance (Cadot et al., 2006; Stephens, Barrett, 2011) and input use and access to extension services (Alene et al., 2008). Moreover, Siziba et al. (2011) observed that extension training and participation in research have positive effects on market participation. Following these studies, age, sex, education, farm size, household labor, non-farm income earning activates, access to credit, market information, value of produced crops, income from livestock, and non-farm income are used in Probit model as independent variables. Thus, the specified Probit regression model for identifying the factors that affect market participation decision of households is formulated in the following way:

$$
\begin{aligned}
& Y_{i}=\beta_{0}+\beta_{1} X_{1}+\beta_{2} X_{2}+\beta_{3} X_{3}+\beta_{4} X_{4}+\beta_{5} X_{5}+\beta_{6} X_{6}+\beta_{7} X_{7}+\beta_{8} X_{8}+\beta_{9} X_{9}+\beta_{10} X_{10} \\
& +\beta_{11} X_{11}+u_{i} \ldots \ldots \ldots \ldots \ldots \ldots \ldots \ldots \ldots \ldots \ldots \ldots \ldots \ldots \ldots \ldots \ldots \ldots \ldots \ldots \ldots \ldots \ldots \ldots
\end{aligned}
$$

Where,

$\mathrm{Y}_{\mathrm{i}}$ refers to market participation decision by a household $(\mathrm{Y}=1$, if farmers participate in the market and $Y=0$, otherwise); $X_{1}, X_{2}, \ldots \ldots . ., X 11$ are explanatory variables that affect the market participation decision; $\beta_{0}, \ldots \ldots \ldots, \beta_{11}$ are parameters to be estimated; and $u_{i}$ is the stochastic disturbance term. The Probit regression model adds the condition of normally distributed variables that can be formulated as:

$$
\mathrm{P}(\mathrm{Y}=1 / \mathrm{X})=\mathrm{F}(\mathrm{Ii})=\frac{1}{\sqrt{2 \Pi}} \int_{-\alpha}^{I_{l}} e^{-z^{2} / 2} d z
$$

Where,

$\mathrm{I}_{\mathrm{i}}=\beta_{0+} \beta_{1} \mathrm{X}_{1+} \ldots \ldots \ldots \ldots+\beta_{11} \mathrm{X}_{11}=$ utility index (latent variable); $\mathrm{P}(\mathrm{Y}=1 / \mathrm{X})=$ the probability 
of market participation; $\mathrm{Z}=$ the standard normal variable, and $\mathrm{F}=$ the standard normal CDF. Gujarati (2003) explains the behavior of a dichotomous dependent variable as we need to use a suitable CDF (cumulative distribution function). The CDF is a function, which can be used in the regression model where the dependent variable is dichotomous taking the values of 0 or 1 . That is, CDF of a random variable $\mathrm{X}$ is simply the probability that is takes a value less than or equal to $\mathrm{x}_{0}$, where $\mathrm{x}_{\mathrm{o}}$ is some specified numerical value of $\mathrm{X}$. The estimating model that emerges from the normal CDF is popularly known as the Probit model, although sometimes it is also known as the normit model. In the selection equation(2), that is, the Probit model, the dependent variable is a dichotomous variable 'participation decision in the output market (represented as 1 when a household participates in the market and 0 otherwise'). The independent variables that condition the participation of smallholder farmers as adapted from literature are sex of household head, age of household head, level of education, farm size, household labor, non-farm activities, use of credit, market information, income from livestock, non-farm income, farm income. These explanatory variables are specified in Table 2 with their expected sign are assumed.

Table 2. Definition of Hypothesized Effects of Explanatory Variables on Market Participation

\begin{tabular}{|c|c|c|c|}
\hline Variable Name & Variable Type & $\begin{array}{c}\text { Variable definition and } \\
\text { measurement }\end{array}$ & $\begin{array}{c}\text { Hypothesized } \\
\text { Effect on Market } \\
\text { Participation }\end{array}$ \\
\hline Sex of Farmer & Dummy & $\begin{array}{l}1 \text { if household head is male, } \\
\text { otherwise } 0\end{array}$ & + \\
\hline Age of Farmer & Continuous & $\begin{array}{l}\text { Age of the household head } \\
\text { (years) }\end{array}$ & - \\
\hline Experience of Farmer & Continuous & $\begin{array}{l}\text { No. years engaged in crop } \\
\text { production (years) }\end{array}$ & + \\
\hline Level of Education & Continuous & $\begin{array}{l}\text { Formal education of the } \\
\text { household head (years of } \\
\text { schooling) }\end{array}$ & + \\
\hline Farm Size & Continuous & $\begin{array}{l}\text { Amount of land under } \\
\text { cultivation of farm } \\
\text { household (Bigha) }\end{array}$ & + \\
\hline Household labor & Continuous & $\begin{array}{l}\text { Number of active family } \\
\text { members working on } \\
\text { the family farm (aged } \\
15-60 y r s \text { ) }\end{array}$ & + \\
\hline Non-farm Activities & Dummy & $\begin{array}{l}1 \text { if participated and o } \\
\text { otherwise }\end{array}$ & - \\
\hline Use of Credit & Dummy & $\begin{array}{l}1 \text { if took credit and o } \\
\text { otherwise }\end{array}$ & + \\
\hline Market Information & Dummy & $\begin{array}{l}1 \text { if accessible of market } \\
\text { information and o if not }\end{array}$ & + \\
\hline Income from Livestock & Continuous & $\begin{array}{l}\text { Total value of livestock } \\
\text { sold in the production year } \\
\text { (Tk) }\end{array}$ & - \\
\hline
\end{tabular}




\begin{tabular}{|l|l|l|c|}
\hline \multicolumn{1}{|c|}{ Variable Name } & Variable Type & \multicolumn{1}{|c|}{$\begin{array}{c}\text { Variable definition and } \\
\text { measurement }\end{array}$} & $\begin{array}{c}\text { Hypothesized } \\
\text { Effect on Market } \\
\text { Participation }\end{array}$ \\
\hline Non-farm Income & Continuous & $\begin{array}{l}\text { Total income earned from } \\
\text { non-farm activities in the } \\
\text { production year }\end{array}$ & - \\
\hline Farm Income & Continuous & $\begin{array}{l}\text { Total value of crops } \\
\text { produced in the last } \\
\text { production year (Tk) }\end{array}$ & + \\
\hline
\end{tabular}

Source: Authors' definitions

\section{Results and Discussion}

In this section, descriptive statistics of the variables and the estimation results of the Probit regression are presented. The results will facilitate to identify the factors that influence a smallholder farmer to participate in the output market to sell his produced crops.

\section{Descriptive Statistics of the Variables}

The collected data from 100 smallholder farmers are analyzed to portray the relevant demographic, social, economic and farm specific features of the farmers. We have found that these features of all farmers are not same and there are significant variations across farmers. The key features of the variables used in the present study are shown in Table 3. From the table it is found that average age of the household head is 44.08 years with maximum of 65 years and minimum of 25 years. The average level of education of farmers in the study area is 5.4 years of schooling with minimum of no education and maximum of 20 years of schooling. All farmers in the study area do not have same experience.

Table 3. A Brief Description of Collected Data

\begin{tabular}{|l|c|c|c|c|}
\hline $\begin{array}{l}\text { Socio-economic and Farm } \\
\text { Characteristics }\end{array}$ & Minimum & Maximum & Mean & Stdv. \\
\hline Age of farmer (years) & 18 & 65 & 44.08 & 11.08 \\
\hline Education (years of schooling) & 0.0 & 20 & 5.40 & 5.27 \\
\hline Experience of farmer (years) & 4 & 55 & 25.73 & 11.61 \\
\hline Farm size (in bigha) & 0.65 & 7 & 4.01 & 1.82 \\
\hline Household labor (person) & 1 & 3 & 1.15 & 0.61 \\
\hline Income from livestock (tk.) & 0.0 & 110,000 & 20,244 & $25,822.9$ \\
\hline Non-farm income (tk.) & 0.0 & 400,000 & 37,252 & $61,529.4$ \\
\hline Farm income (tk.) & 10,900 & 316,000 & 80,110 & $80,968.2$ \\
\hline
\end{tabular}

Source: Authors' calculations according to data from Osmani, Hossain (2013) 
From the table it is found that the average experience of the sample farmers is 25.73 years, whereas the minimum experience is 4 years and maximum experience is 55 years. The farms of different sizes are found in the study area. From Table 3, it is observed that the average farm size of sample farmer is 4.01 bigha indicating that most of the farmers in the study area are smallholder. Smallholder farmers cultivate their land by both family labor and hired labor. However, number of active family labor varies across households. The average number of active household labor is found 1.15 per household with maximum of 3 persons and minimum of 1 person. From Table 3, it is also seen that average annual income from livestock asset is Tk.20,244 (Taka - currency of Bangladesh), average annual non-farm income is Tk. 37,252, and average annual farm income is Tk. 80,110.

\section{Market Participation of Smallholder farmers}

Analysis of household market participation indicates that the households in the study area are moderately market participators. A statistical summary of crop value produced and sold with market participation status of the sample households are shown in table 4 . The statistical summary given in table 4 shows that a typical household head produced crops valued approximately Tk.104,110 ranging from Tk.10,900 to Tk.416,000. From sells dimension, a typical household head, on average, sold food crops worth Tk.71,185 ranging from selling nothing to Tk.321,000. The market participation for the typical household head is computed to be 0.57 which indicates that on average a typical household sells $57 \%$ of his total crop production ranging from selling o $\%$ to $95 \%$. This indicates that the level of market participation in the study areas is neither very low nor very high.

Table 4. Market Participation of Smallholder Farmers (Crop Produced and Sold in Taka)

\begin{tabular}{|l|c|c|c|c|c|}
\hline \multicolumn{1}{|c|}{ Variable } & Sample & Min. & Max. & Mean & Std. Dev. \\
\hline $\begin{array}{l}\text { Total value of crop } \\
\text { produced }\end{array}$ & 100 & $10,900.00$ & 416,000 & 104,110 & $80,968.24$ \\
\hline Total value of crop sold & 100 & 0.00 & 321,000 & 71,185 & $71,815.05$ \\
\hline Market participation & 100 & 0.00 & 0.95 & 0.57 & 0.26854 \\
\hline
\end{tabular}

Source: Authors' calculations according to data from Osmani, Hossain (2013)

\section{Regression Results of Market Participation Decision}

In order to achieve the purpose of the study, several demographic and socioeconomic variables, which are believed to have an influence on the decision to participate in the market, are included in the Probit regression. The estimation results are presented in Table 5.

Table 5. Probit Analysis of Determinants of Decision of Market Participation by Smallholder Farmers

\begin{tabular}{|l|c|c|c|c|}
\hline \multicolumn{1}{|c|}{ Variable } & Coefficient & Std. Err. & Z-value & $\mathbf{P}>|\mathbf{z}|$ \\
\hline Sex & 0.88 & 1.38 & 0.64 & 0.524 \\
\hline Age & -0.02 & 0.03 & -0.61 & 0.543 \\
\hline Level of Education & -0.04 & 0.07 & -0.52 & 0.604 \\
\hline Farm Size & $0.70^{* * *}$ & 0.21 & 3.31 & 0.001 \\
\hline
\end{tabular}




\begin{tabular}{|c|c|c|c|c|}
\hline Variable & Coefficient & Std. Err. & Z-value & $\mathbf{P}>|\mathbf{z}|$ \\
\hline Household Labor & $1.08 * * *$ & 0.50 & 2.17 & 0.030 \\
\hline Non-farm Activities & -0.55 & 0.60 & -0.91 & 0.361 \\
\hline Use of Credit & -0.34 & 0.60 & -0.57 & 0.567 \\
\hline Market information & -0.40 & 0.64 & -0.63 & 0.531 \\
\hline Income from Livestock & $-0.001 * * *$ & 0.01 & -2.52 & 0.012 \\
\hline Non-farm Income & -0.0000061 & 0.0000084 & -0.73 & 0.464 \\
\hline Farm Income & $0.0000057^{*}$ & 0.0000032 & 1.76 & 0.078 \\
\hline Constant & -4.27 & 2.40 & -1.78 & 0.074 \\
\hline $\begin{array}{c}\text { Log likelihood }=-21.072235 \\
\text { LR chi2 }(11)=80.03 \\
\text { Prob. }>\text { chi2 }=0.0000 ; \text { Pseudo } \\
\text { R2 }=0.6550\end{array}$ & & & & \\
\hline
\end{tabular}

Source: Authors' calculations according to data from Osmani, Hossain (2013)

Note: $* * *, * *$ and $*$ indicates $1 \%, 5 \%$ and $10 \%$ significance level

From Table 5, it can be observed that the likelihood ratio statistics as indicated by chi-square statistics are highly significant $(\mathrm{P}<0.0000)$, suggesting the model has a strong explanatory power. The Pseudo R2 is 0.6550 , indicating the specification fits the data well the variables included in the model explain $65 \%$ of the variation in the decision of market participation of farmers. Table 4 also indicates that the estimated coefficients of the Probit regression revealed that the explanatory variables- 'farm size', 'household labour' and 'farm income' positively and significantly influence the farmers' decision to participate in the market with crop sales. On the other hand, 'income from livestock' has significant negative impact on the decision of the smallholder farmers to participate in the market.

The Probit estimation result in Table 5 reveals that the variable 'farm size' is statistically significant at $1 \%$ level and has positive influence on the decision for market participation of households. This means that as the farm size increases, the probability of decision for commercialization increases. This result is in line with Okezie et al. (2012), Goshu et al. (2012) and Gebreselassie and Sharp (2008). This could be due to the role of farm size in boosting total production level and thus sales of surplus produce. Moreover, farm households with large farm size could allocate their land partly for food crop production and partly for cash crop production giving them better position to participate in the output market. Martey et al. (2012) had opined that farm size influences the level of agricultural commercialization in a study in Ghana. This study corroborates their result.

The Probit results show that 'household labor' has a positive effect, at a significance level of $1 \%$, on the decision of households to participate in the output market. The sign of the coefficient is positive and it means that if a farm family has more active labour, its probability to taking decision of participating in the output market increases. This result is consistent with Gebremedhin and Jaleta (2010b). Therefore, this seems reasonable since households with a large number of active household labors can reduce their cost of production and produce surplus to be market-oriented. 
Econometric analysis reveals that 'farm income' is another important variable having significantly positive impact on the decision of smallholder farmers to participate in the output market. It is statistically significant at $10 \%$ level indicating that households with high level of production tend to participate in the output market than those with lower production level. This means that farmers' decision on market entry is significantly related to the amount of farm production. This is due to the fact that households with higher value of produced crop sell higher proportion of their produce and thus, increase the probability to participate in market. This finding is similar to the finding of Gebreselassie and Sharp (2008), as well as Gebremedhin and Jaleta (2010b).

Moreover, the coefficient of income from livestock is found to have a statistically significant at $1 \%$ level and it negative influence on the probability of households to participate in the output market. This means that as income from livestock of the farmer's increases, the probability of farmers' orientation towards commercialization in the study area reduces. Thus, farmers with high degree of participation in the livestock market may less efficient in enhancing their productivity, thus farmers have a less chance of achieving surplus production for sale.

Contrary to earlier expectations, the variable- sex, age, education level, participation in nonfarm activities, use of credit, market information and non-farm income are found to have no significant impact on the decision of the farmers to towards commercialization. Moreover, the direction of influence of some are found opposite to our expectation. For example, education level is found to have unexpected negative sign. The possible explanation for this might be the fact that most of the young household heads are motivated towards other occupations than cultivation.

To facilitate interpretation of the estimation results presented in Table 5, the marginal effects of each variable on the predicted probability of households' market participation, evaluated at the means of the explanatory variables, are reported in Table 6. The marginal effects report of the Probit regression provides the probability that a farm household will participate in output markets. Table 6 provides the probability estimation for the likelihood of market participation of a farm household given the statistically significant variables: 'farm size', 'household labor', 'income from livestock', and 'farm income'.

The marginal effect report of the Probit regression in Table 6 indicates that there is a probability of $13 \%$ that a farmer participates in the output market if his farm size increases, at mean value, by one bigha. The marginal effect shows that there is a probability of approximately $20 \%$ that a smallholder participates in the output market if he manages to have a mean of one additional active household labour. Similarly, the probability that a smallholder farmer will participate in an output market as a result of a one taka increase, at mean value, in the farm income is given by $0.0001 \%$. In other words, if the farm income of a farmer increases by Tk. 1000, at mean value, then the likelihood of participation in the market increases by $0.1 \%$. 
Table 6. Marginal Effects of the Explanatory Variables Used to Estimate Probit Regression

\begin{tabular}{|l|c|c|c|c|c|}
\hline Variable & $\mathbf{d y} / \mathbf{d x}$ & Std. Err. & $\mathbf{Z}$ & $\mathbf{P}>|\mathbf{z}|$ & $\mathbf{x}-\mathbf{b a r}$ \\
\hline Sex & 0.092 & 0.07 & 0.64 & 0.524 & 0.98 \\
\hline Age & -0.003 & 0.01 & -0.61 & 0.543 & 44.08 \\
\hline Level of Education & -0.007 & 0.01 & -0.52 & 0.604 & 5.40 \\
\hline Farm Size & $0.128^{* * *}$ & 0.05 & 3.31 & 0.001 & 4.07 \\
\hline Household Labor & $0.198^{* *}$ & 0.09 & 2.17 & 0.030 & 1.17 \\
\hline $\begin{array}{l}\text { Non-farm } \\
\text { Activities }\end{array}$ & -0.107 & 0.12 & -0.91 & 0.361 & 0.58 \\
\hline Use of Credit & -0.061 & 0.10 & -0.57 & 0.567 & 0.43 \\
\hline Market information & -0.080 & 0.14 & -0.63 & 0.531 & 0.66 \\
\hline $\begin{array}{l}\text { Income from } \\
\text { Livestock }\end{array}$ & $-0.000005^{* * *}$ & 0.0000024 & -2.52 & 0.012 & 20239 \\
\hline Non-farm Income & -0.000001 & 0.0000014 & -0.73 & 0.464 & 37252 \\
\hline Farm Income & $0.000001 *$ & 0.0000007 & 1.76 & 0.078 & 10411 \\
\hline $\begin{array}{l}\text { Observed } \\
\text { Probability }\end{array}$ & 0.3 & & \\
\hline $\begin{array}{l}\text { Predicted } \\
\text { probability }\end{array}$ & $0.1066888 \quad$ (at x-bar) \\
\hline $\begin{array}{l}\text { Log likelihood = -21.072235; Number of obs. =100; } \\
\text { LR chi2 (11) = 80.03; Prob.> chi2 = 0.0000; Pseudo R2 }=0.6550\end{array}$ \\
\hline
\end{tabular}

Source: Authors' calculations according to data from Osmani, Hossain (2013)

Finally, the marginal effect report of the Probit regression in Table 6 shows that if a farmers' income from livestock increases by one Taka, then there are $0.0005 \%$ likelihoods that he would not take part in the output market since the coefficient of this variable is negative.

\section{Conclusion}

Smallholder farmers in Bangladesh have potential to contribute to economic growth and development. Market participation of smallholder farming is getting priority in the developing world in general and Bangladesh in particular. Lack of full participation in markets prevents them from transiting into commercial farming and hence their low contribution to economic growth. They are constrained by a number of factors in marketing, making it difficult for them to commercialize; such institutional, technical and socio-economic factors include lack of information, poor infrastructure, inability to have contractual agreements, lack of transport, poor organizational support, low access to extension agents, low use of improved seed and low use of fertilizer with relatively small marketable surplus. Thus, majority of the farmers are still into subsistence farming as they will only go to market to sell the excess after consuming enough by the households.

The results of the present study demonstrate that households in the study area are characterized by a high productivity but with moderate degree of market participation. The average share sold by the smallholder farmers is found to be $57 \%$ of their total crop productions. Moreover, there are both positive and negative significant relationships in the Probit model inferred that farm size, household labour and farm income are positively and on the contrary, income from 
livestock is inversely related to the market participation decision of smallholder farmers in the study area. Following the constraints and effective factors, the study recommends that efforts should be made at upgrading roads and support establishment of more points of sales in farming areas in order to lower transportation costs to promote market participation. It is also important to consider the non-homogeneity of smallholder farmers' in terms of education, location and availability of other assets and youths should be encouraged to participate in agricultural production to inject new blood into the current production system.

\section{Literature}

1. Alene, A. D., Manyong, V. M., Omanya, G., Mignouna, H. D., Bokanga, M., Odhiambo, G. (2008): Smallholder market participation under transaction costs: Maize supply and fertilizer demand in Kenya, Food Policy, vol. 33, no. 4, pp. 318-328.

2. BBS (2010): Labour Force Survey, Bangladesh Bureau of Statistics, Ministry of Finance, Government of the People's Republic of Bangladesh, available at: www.bbs. gov.bd/userfiles/Image/Survey\%20reports/Labour\%20Force\%20Survey\%202010.pdf

3. BBS (2011): Bangladesh Population Census, Bangladesh Bureau of Statistics, Ministry of Finance, Government of the People's Republic of Bangladesh, available at: www.bbs. gov.bd/RptPopCen.aspx?page=/PageReportLists.aspx?PARENTKEY=41

4. BBS (2013): Macroeconomic indicators, Bangladesh Bureau of Statistics, Ministry of Finance, Government of the People's Republic of Bangladesh, available at:

http://bbs.gov.bd/WebTestApplication/userfiles/Image/GDP/GDP 2013-14.pdf

5. Cadot, O., Dutoit, L., Olarreaga, M. (2006): How Costly Is It for Poor Farmers to Lift Themselves Out of Subsistence?, Policy Research Working Paper 3881, World Bank, Washington, USA, available at: http://my.unil.ch/serval/document/BIB BC066A337035.pdf

6. Chirwa, E. W., Matita, M. (2012): From Subsistence to Smallholder Commercial Farming in Malawi: A Case of NASFAM Commercialization Initiatives, Future Agricultures, Brighton, UK, Working Paper 037, pp. 1-20.

7. Egbetokun, O. A., Omonona, B. T. (2012): Determinants of Farmers' Participation in Food Market in Ogun State, Global Journal of Science Frontier Research Agriculture and Veterinary Sciences, vol. 12, no. 9, Version 1.0, pp. 24-30.

8. Ele, I. E., Omini, G. E., Adinya, B. I. (2013): Assessing the Extent of Commercialization of Smallholding Farming Households in Cross River State, Nigeria, IOSR Journal of Agriculture and Veterinary Science (IOSR-JAVS), vol. 4, no. 2, pp. 49-55.

9. Eskola, E. (2005): Commercialization and Poverty in Tanzania: Household-Level Analysis, Discussion Paper, Department of Economics, University of Copenhagen, Copenhagen.

10. Gebremedhin, B., Jaleta, M. (2010a): Commercialization of Smallholders: Is Market Participation Enough?, Joint $3^{\text {rd }}$ African Association of Agricultural Economists (AAAE) and $48^{\text {th }}$ Agricultural Economists Association of South Africa (AEASA) Conference, Cape Town, South Africa.

11. Gebremedhin, B., Jaleta, M. (2010b): Commercialization of smallholders: Does market orientation translate into market participation?, International Livestock Research Institute (ILRI), Improving Productivity and Market Success (IPMS) of Ethiopian farmers project Working Paper no. 22, Nairobi, Kenya. 
12. Gebreselassie, S., Ludi, E. (2008): Agricultural Commercialisation in Coffee Growing Areas of Ethiopia, Future Agriculture, University of Sussex, Brighton, UK, available at: http://r4d.dfid.gov.uk/PDF/Outputs/Futureagriculture/coffee paper.pdf

13. Gebreselassie, S., Sharp, K. (2008): Commercialisation of Smallholder Agriculture in Selected Tef-growing Areas of Ethiopia, Future Agricultures Consortium, A discussion paper, University of Sussex, Brighton, UK, available at: www.future-agricultures.org/publications/ research-and-analysis/discussion-papers/26-commercialisation-of-smallholder-agriculturein-selected-tef-growing-areas-of-ethiopia/file

14. Government of Bangladesh (GoB), (2008): e.Krishi Vision 2025: Service at Farmers' Doorsteps, A report prepared by "Access to Information"(A2I) Programme, Prime Minister's Office in collaboration with Ministry of Agriculture and concerned agencies with assistance from MDGs and Pro-Poor Development Programme, UNDP, Prime Minister's Office Old Sangshad Bhaban Tejgaon, Dhaka1215 Bangladesh, available at: www.a2i.gov.bd/sites/default/files/resource_docs/eKrishi\%20Vision-2021.pdf

15. GoB (2014): Bangladesh Economic Review, Department of finance, Ministry of Finance and Planning, Government of the People's Republic of Bangladesh, Dhaka, pp. 71.

16. Goletti, F. (2005): Agricultural Commercialization, Value Chains and Poverty Reduction, Making Markets World Better for the Poor Discussion Paper no.7, Hanoi: Asian Development Bank.

17. Goshu, D., Kassa, B., Ketema, M. (2012): Measuring Smallholder Commercialization Decision and Interaction in Ethiopia, Journal of Economics and Sustainable Development, vol. 3, no. 13, pp. 150-160.

18. Gujarati, D. N. (2003): Basic Econometrics, $4^{\text {th }}$ Edition, Tata Mc-Graw-Hill Publishing Company Limited, New Delhi, India.

19. IFAD (2001): The Challenge of Ending Rural Poverty, Rural Poverty Report-2001, Oxford University Press Inc., NY, USA.

20. Martey, E., Al-Hassan, R. M., Kuwornu, J. K. M. (2012): Commercialization of smallholder agriculture in Ghana: A Tobit regression analysis, African Journal of Agricultural Research, vol. 7, no. 14, pp. 2131-2141.

21. MoA (2013): Annual report 2012-13, Ministry of Agriculture, Government of the People's Republic of Bangladesh, available at: www.moa.gov.bd/site/view/annual reports

22. Moyo, T. (2010): Determinants of Participation of Smallholder Farmers in the Marketing of Small Grains and Strategies for Improving Their Participation in the Limpopo River Basin of Zimbabwe, Unpublished MSc. thesis, University of Pretoria, Pretoria, South Africa.

23. Ohen, S. B., Etuk, E. A., Onoja, J. A. (2013): Analysis of Market Participation by Rice Farmers in Southern Nigeria, Journal of Economics and Sustainable Development, vol. 4, no. 7, pp. 6-11.

24. Okezie, C. A., Sulaiman, J., Nwosu, A. C. (2012): Farm - Level Determinants of Agricultural Commercialization, International Journal of Agriculture and Forestry, vol. 2, no. 2, pp. 1-5.

25. Olwande, J., Mathenge, M. (2012): Market Participation among the Poor Rural 
Households in Kenya, A paper prepared for presentation at the International Association of Agricultural Economists (IAAE) Triennial Conference, Foz do Iguaçu, Brazil, available at: http://ageconsearch.umn.edu/bitstream/126711/1/Olwande.pdf

26. Omiti, J. M., Otieno, D. J., Nyanamba, T. O., McCullough, E. (2009): Factors Influencing the Intensity of Market Participation by Smallholder Farmers: A Case Study of Rural and Peri-Urban Areas of Kenya, African Journal of Agricultural and Rural Economics, vol. 3, pp. 57-82.

27. Onoja, O., Usoroh, B. B., Adieme, D. T., Deedam N. J. (2012): Determinants of Market Participation in Nigerian Small Scale Fishery Sector: Evidence from Niger Delta Region, Journal of Sustainable Development, vol. 9, no. 1, pp. 69-84.

28. Osmani, M.A.G., Hossain, E. (2013): Household survey-2013: Commercialization of smallholder farmers and its welfare outcome, Department of Economics, University of Rajshahi, Rajshahi-6205, Bangladesh.

29. Pender, J., Ehui, S., Place, F. (2006): Conceptual framework and hypothesis, In: Pender, J., Place, F., Ehui, S. (Eds.), Strategies for sustainable land management in the East African highlands, IFPRI (International Food Policy Research Institute), Washington DC, USA.

30. Pender, J., Alemu, D. (2007): Determinants of smallholder commercialization of food crops: Theory and evidence from Ethiopia, IFPRI (International Food Policy Research Institute), Discussion Paper No. 75, Washington DC, USA.

31. Pingali, L. P., Rosegrant, M. W.(1995): Agricultural commercialization and diversification: Process and polices, Food Policy, vol. 20, no. 3, pp. 171-185.

32. Pingali, P. (1997): From subsistence to commercial production System: The transformation of Asian agriculture, American Journal of Agricultural Economics, vol. 79, no. 2, pp. 628634.

33. Rahut, D. B., Castellanos, I. V., Sahoo, P. (2010): Commercialization of Agriculture in the Himalayas, Institute of Development Economics (IDE), discussion Paper No. 265, Chiba, Japan.

34. Randela, R., Alemu, Z. G., Groenewald, J. A. (2008): Factors Enhancing market participation by small scale farmers, Agrekon, vol. 47, no. 4, pp. 451-469.

35. Razzaque, M. A., Hossain, M. G. (2007): Country Report on the State of Plant Genetic Resources for Food and Agriculture, Ministry of Agriculture Bangladesh.

36. Sadoulet, E., de Janvry, A. (1995): Quantitative development policy analysis, The Johns Hopkins University Press, Baltimore, Maryland, USA.

37. SFB (2015): Improving the Livelihood of Smallholder Farmers, Syngenta Foundation Bangladesh, available at: www.syngentafoundation.org/index.cfm?pageID $=579$

38. Sharma, V. P., Jain, D., Sourovi, D. (2012): Managing agricultural commercialization for inclusive growth in South Asia, Agriculture Policy Series, Briefing Paper No. 6/2012, GDN, New Delhi, India.

39. Siziba, S., Nyikahadzoi, K., Diagne, A., Fatunbi A. O., Adekunle, A. A. (2011): Determinants of cereal market participation by sub-Saharan Africa smallholder farmer, Journal of Agriculture and Environmental Studies, vol. 2, no. 1, pp. 180-193.

40. Stephens, E. C., Barrett, C. B. (2011): Incomplete credit markets and commodity marketing behaviour, Journal of Agricultural Economics, vol. 62, no. 1, pp. 1-24. 
41. Thapa, G., Gaiha, R. (2011): Smallholder Farming in Asia and the Pacific: Challenges and Opportunities, Paper presented at the IFAD Conference on New Directions for Smallholder Agriculture, IFAD, Rome, Italy.

42. von Braun, J., de Haen, H., Blanken, J. (1991): Commercialization of agriculture under population pressure: Effects on production, consumption and nutrition in Rwanda, Research Report 85, IFPRI (International Food Policy Research Institute), Washington, DC, USA.

43. von Braun, J., Immink, M. D. C. (1994): Non-traditional vegetable crops and food security among smallholder farmers in Guatemala, In: von Braun J and Kennedy E (eds), Agricultural commercialization, economic development, and nutrition, Johns Hopkins University Press, Baltimore, Maryland, USA, pp. 189-203.

44. World Bank (2007): World Development Report 2008: Agriculture for development: Overview, Washington, DC, USA. available at: http://siteresources.worldbank.org/ INTWDR2008/Resources/WDR 00 book.pdf

45. World Bank (2015): Pairing Agriculture with Technology in Bangladesh, Washington, DC, USA, World Bank Group, available at: www.worldbank.org/en/news/ feature/2014/06/23/pairing-agriculture-with-technology-in-bangladesh 